\section{Chemical warfare}

\section{Fight amongst Finnish}

The publication last week of the report of the United Nations on allegations that the Soviet Union and Vietnam have been in Afghanistan and South East Asia has caused some embarrassment to the Finnish foreign minister Paer Stenbaeck, who refused to let his ministry assist the enquiry. According to the independent newspaper Laensi-Savo, the minister was "mixing up the work of Finland's Technical Research Institute with our foreign policy's credibility",

The implication from comments in the Finnish media is that there has been a conflict over the freedom to research, with Mr Stenbaeck forbidding the project and the head of the Technical Research Institute (VTT) Dr Pekko Jauho insisting on the research going ahead.

During the past ten years, Finland has built up, under the supervision of the foreign ministry, a chemical warfaremonitoring capability which involves a number of laboratories and institutions mainly civilian - including VTT. This capability, the Finns hope, will ultimately be used under the auspices of international agreements banning chemical warfare. Meanwhile the Finns have built up a considerable body of experience, and it was instructions. using chemical warfare against insurgents

reasonable, after the pledges of successive Finnish governments to support the United Nations in every aspect of its peacekeeping role, that the UN enquiry team should approach the Finns for assistance in analysing vegetation and blood samples from South-East Asia.

But Mr Stenbaeck was reluctant to let his ministry help. He felt, apparently, that without the guaranteed conditions for impartial and neutral verification which would presumably be embodied in a future treaty, it could damage his ministry's credibility to be involved in such a contentious issue as the allegations of chemical warfare in South East Asia. In particular, he had considerable doubts about the provenance of the samples, which had been brought to Finland without prior notification or agreement. The sample delivered to the Finnish Foreign Ministry was accordingly returned to the United Nations unopened, apparently on Mr Stenbaeck's direct

The other two samples were delivered to two scientists working for VTT, Professor Tor-Magnus Enari, an expert on Fusarium, and Professor Rolf Rosenbere, a physicist working in neutron-activation analysis. VTT, a government establishment responsible to the ministry of trade

\section{Japan plans DNA database \\ Washington}

Japan's entry into the field of molecular genetics may include a central data bank for DNA sequences. Storage of these complex sequences in computers and their statistical comparison have opened up new analytical possibilities in the field.

Some Japanese scientists attending a recent workshop in Aspen, Colorado, expressed an interest in starting such a database, and the scientists who run the new US database at the Los Alamos National Laboratory have welcomed their interest. The Japanese Ministry of Education may decide on 7 January 1983 to fund the project.

The database, likely to be located at the University of Tokyo, could be linked electronically to the Los Alamos database and to that run by the European Molecular Biology Laboratory (EMBL) at Heidelberg, West Germany.

A crucial question is which sequences it should collect. It would clearly be useful to collect the sequences published sometimes in Japanese - in the Japanese scientific literature, which are generally unavailable to the groups at Los Alamos and Heidelberg. On the other hand, the number of sequences published in the Japanese journals is so far rather small, so that the database may be expanded to include those published abroad as well.

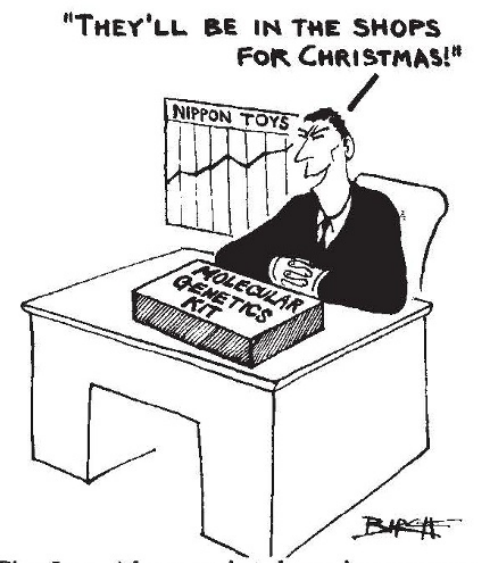

The Los Alamos database is supposed to contain all published sequences by July 1983, according to the terms of the contract that the US National Institutes of Health awarded to Bolt, Beranek and Newman for the Los Alamos-based project, known as GenBank. Walter Alamos, said last week that sequences with an estimated 750,000 bases had been entered into his system, and that by the July 1983 deadline, it may include as many as 2 million bases. The GenBank database has just been announced "as available to the public for a nominal fee".

Deborah Shapley Goad, the principal investigator at Los and industry, operates a wide programme of contract research and development for both Finnish and foreign customers, and the UN commission was accepted as a purely commercial proposition. The work duly went ahead, giving, as it turned out, entirely negative results.

Vera Rich

\section{UK nuclear power}

\section{PWRs "safe"}

A new report from the Advisory Committee on the Safety of Nuclear Installations (ACSNI) concludes that the Central Electricity Generating Board (CEGB) will be able to reach acceptable standards of safety for Britain's first pressurized water reactor (PWR), but draws attention to a number of areas in which it feels further work will be needed. In this respect it is substantially in agreement with the Nuclear Installations Inspectorate (NII) report earlier this year.

Some of the points raised by the document are sure to be used by objectors at the forthcoming public inquiry into the proposed PWR at Sizewell to embarrass CEGB, but the board seems confident that the questions raised in the ACSNI report have been answered since the end of 1981 (the latest date for ACSNI's evidence). This may explain some of the report's apparent ambiguities. In particular, CEGB's design proposals in its Preconstruction Safety Report have already been modified to include a doublecontainment system for the reactor pressure vessel, in accordance with current French and German practice.

ACSNI, set up to report to the Health and Safety Commission, attempts only to review the technical work of others and considers only selected aspects of PWR safety. The areas considered, by separate study groups, were the integrity of the pressure vessel, the plant/operator interface, and fuel processing. Most of the potential problem areas highlighted by ACSNI lie in the first two catagories. Besides echoing NII's insistence on the highest achievable quality control of steel components in the reactor vessel itself, the report asks for equivalent standards to be applied to the whole of the coolant system. Standards for testing the integrity of welds are questioned, and more work is requested on degraded core phenomena. One of ACSNI's most significant criticisms of the CEGB Preconstruction Safety Report concerns the possibility of multiple breaks in the steam generator tubes, a consideration apparently excluded by CEGB on the grounds of unlikelihood. Since that time such an accident has in fact happened, and resulted in the release of some radioactivity.

On the subject of the plant/operator interface (one of the main causes of the accident in the PWR at Three Mile Island) the report makes recommendations about management and training schemes, and 